\title{
Analisis Kemampuan Koneksi Matematis Siswa Pada Materi Trigonometri
}

\author{
Arrum Agitiya Ningsih ${ }^{1}$, Citra Utami ${ }^{2}$, Rika Wahyuni ${ }^{3}$ \\ STKIP Singkawang, Singkawang, Indonesia \\ Arrumningsih@gmail.com ${ }^{1}$, Citrautami1990@gmail.com ${ }^{2}$, Rikawahyuni142@gmail.com³
}

\section{Keywords :}

Analisis, Kemampuan Koneksi

Matematis, Trigonometri

\begin{abstract}
Penelitian ini bertujuan untuk mendeskripsikan tingkat kemampuan koneksi matematis siswa, kesalahan siswa dalam menyelesaikan soal trigonometri berdasarkan indikator kemampuan koneksi matematis siswa, dan faktor yang mempengaruhi siswa melakukan kesalahan dalam menyelesaikan soal trigonometri berdasarkan indikator kemampuan koneksi matematis siswa pada kelas XI di SMA Negeri 10 Singkawang. Penelitian ini menggunakan description research. Subjek penelitian ini adalah 30 siswa kelas XI IPA di SMA Negeri 10 Singkawang. Instrument soal yang digunakan dalam penelitian ini berupa 3 buah soal tes tertulis yang mengacu pada indikator kemampuan koneksi matematis siswa. Teknik analisis data yang digunakan dalam penelitian ini adalah teknik analisis interaktif yang terdiri atas tiga komponen yaitu reduksi data, penyajian data, dan penarikan kesimpulan. Hasil penelitian ini, menunjukkan bahwa (1) Tingkat kemampuan koneksi matematis siswa tergolong cukup. (2) Kesalahan dalam menyelesaikan soal trigonometri yang meliputi kesalahan konseptual (salah dalam memahami soal, menggunakan rumus, menerjemahkan soal ke dalam kalimat matematika, menentukan rumus yang akan digunakan, dan salah mementukan jawaban akhir) dan kesalahan prosedural (langkah penyelesaian tidak sistematis, tidak mampu memanipulasi langkah, tidak melanjutkan proses penyelesaian, dan kesalahan dalam melakukan proses perhitungan matematika). (3) Faktor yang mempengaruhi kesalahan siswa dalam menyelesaikan soal meliputi faktor kesalahan konseptual (kurang teliti dalam menyelesaikan soal, kurangnya penguasaan bahasa terhadap permintaan soal, kurangnya pemahaman siswa terhadap materi trigonometri, kurang teliti dalam menyelesaikan soal dan lupa denga rumus yang akan digunakan) dan faktor kesalahan prosedural (kurang teliti dalam melakukan perhitungan, tergesa-gesa dalam menyelesaikan soal, kurangnya pemahaman siswa terhadap materi trigonometri, lupa rumus yang akan digunakan dan tidak memahami maksud soal).
\end{abstract}




\section{PENDAHULUAN}

Matematika merupakan ilmu yang terstruktur dan saling berkaitan antara satu topik dengan topik lainnya (Romli, 2016). Sebagai ilmu yang saling berkaitan, siwa harus memiliki kemampuan dalam menghubungkan antara topik di dalam matematika yang di kaitkan dalam kehidupan sehari -hari, menurut (Buyung, B., \& Nirawati, R. 2018). Matematika mempunyai arti penting dalam membantu manusia menyelesaikan masalah pada kehidupan sehari-hari. Kemampuan untuk menghubungkanantar topik matematika tersebut, terdapat dalam lima kemampuan yang harus dimiliki siswa yang telah ditetapkan oleh National Council of Teacher of Mathematics (dalam Musriliani dkk, 2015) salah satunya yaitu kemampuan koneksi (connection).

Kemampuan koneksi matematis menurut Suherman (Lestari dan Yudhanegara, 2015: 82) adalah kemampuan untuk mengaitkan konsep/aturan matematika yang satu dengan yang lainnya, dengan bidang studi lain, atau dengan aplikasi pada dunia nyata. Sementara, National Council of Teachers Of Mathematics menyebutkan bahwa koneksi matematis adalah keterkaitan antar topik matematika, keterkaitan antara matematika dengan disiplin ilmu yang lain dan keterkaitan matematika dengan dunia nyata atau dalam kehidupan sehari-hari (Romli, 2016). Berdasarkan pemaparan tersebut, dapat disimpulkan bahwa kemampuan koneksi matematis merupakan kemampuan dalam menghubungkan atau mengaitkan konsep matematika yang satu dengan lainnya atau dengan bidang studi lain atau dengan kehidupan sehari-hari.

Materi matematika memiliki keterkaitan antarkonsep satu sama lain. Oleh karena itu, kemampuan siswa dalam mengkoneksikan sangat diperlukan dalam pembelajaran matematika. Hal tersebut sesuai dengan salah satu tujuan mata pelajaran matematika menurut BSNP (2006) yang menyebutkan bahwa agar siswa memiliki kemampuan dalam memahami konsep matematika, menjelaskan keterkaitan antarkonsep dan mengaplikasikan konsep atau logaritma, secara luwes, akurat, efisien, dan tepat, dalam pemecahan masalah. Berdasarkan tujuan mata pelajaran matematika yang telah dipaparkan di atas, terdapat salah satu kemampuan yang harus dimiliki oleh siswa yaitu menjelaskan keterkaitan antarkonsep. Hal tersebut terdapat dalam kemampuan koneksi matematis dimana kemampuan dalam menjelaskan keterkaitan antarkonsep ini, penting dimiliki oleh siswa.

Pentingnya kemampuan koneksi matematis yang harus dimiliki oleh siswa tersebut agar mereka mampu memahami keterkaitan antarara konsep yang satu dengan konsep lainnya dan dapat menghubungkan antara materi yang satu dengan materi yang lainnya. Jika tidak memiliki kemampuan koneksi matematis ini, siswa harus mengingat dan mempelajari banyak konsep dan kemampuannya pun terisolasi. Dengan adanya kemampuan koneksi matematis yang dicapai siswa, maka akan dengan mudah siswa memahami pelajaran matematika yang dipelajarinya. Akan tetapi, kemampuan koneksi matematis yang dicapai pada pelajaran matematika bukanlah suatu hal yang mudah karena kemampuan untuk mengkoneksikan dalam matematika dilakukan secara individual. Setiap siswa memiliki kemampuan yang berbeda dalam mengkoneksikan hubungan dalam matematika sehingga, kemampuan koneksi matematis perlu ditingkatkan supaya siswa mampu memahami arti dan makna pembelajaran matematika yang diberikan oleh guru dalam kehidupan sehari-hari. Apabila siswa dapat menghubungkan konsep-konsep matematika secara matematis, maka siswa akan memiliki pemahaman yang lebih mendalam dan dapat bertahan lebih lama. Selain itu, siswa dapat lebih mudah mempelajari hal baru dengan mempertahankan konsep yang sudah dipahaminya.

Namun kenyataannya dalam pembelajaran matematika, kemampuan koneksi matematis siswa belum maksimal dikembangkan pada sekolah-sekolah di Indonesia. Pembelajaran matematika di sekolah biasanya cenderung hanya bertujuan untuk meningkatkan nilai matematika tanpa memperhatikan mutu dan aspek matematika lain yang saling berkesinambungan. Hal ini menyebabkan siswa di sekolahsekolah Indonesia banyak mengalami kesalahan dalam menyelesaikan permasalahan pada materi matematika. 
Hasil penelitian Warih, dkk (2016) menunjukkan bahwa siswa mengalami kesalahan pada indikator menggunakan hubungan diantara ide-ide matematis dan siswa belum dapat menghubungkan satu konsep dengan konsep lain yang sudah dipelajari untuk menyelesaikan soal koneksi matematis, siswa tidak mengenali ide-ide matematis, dan siswa tidak dapat menggunakan ide-ide matematis. Selain itu, hasil penelitian Citra, dkk (2016) menunjukkan bahwa rata-rata siswa tidak dapat menghubungkan antara konsep matematika yang satu dengan konsep matematika yang lainnya dan siswa tidak dapat memahami dan menerapkan matematika dengan bidang studi lain. Hal tersebut menunjukkan bahwa rendahnya kemampuan koneksi matematis yang dimiliki siswa.

Kemampuan koneksi matematis siswa yang rendah tersebut menunjukkan bahwa kemampuan koneksi matematis penting bagi siswa dalam memudahkan mempelajari materi matematika. Salah satu materi pokok yang penting untuk dipelajari yaitu materi trigonometri. Namun kenyataan menunjukkan bahwa banyak diantara siswa-siswa khususnya siswa sekolah menengah atas tidak dapat menguasai materi trigonometri dengan benar. Hal ini dibuktikan dengan penelitian terdahulu yang menyangkut dengan penguasaan siswa sekolah menengah atas terhadap materi trigonometri yaitu hasil penelitian dari Aqiilah (2012) menunjukkan bahwa siswa masih banyak melakukan kesalahan dalam menyelesaikan soal trigonometri dan kesalahan tersebut hampir terjadi pada setiap butir soal. Selain itu, penyebab kesalahan tersebut antara lain kurang terampilnya siswa dalam mengoperasikan soal dan tidak memahami maksud soal tersebut. Hal tersebut menunjukkan kurangnya pengetahuan dan pemahaman siswa pada materi trigonometri.

Berdasarkan hasil wawancara dengan guru matematika SMA Negeri 10 Singkawang kelas XI IPA, diketahui bahwa hasil belajar siswa pada materi trigonometri masih tergolong rendah. Rendahnya hasil belajar siswa pada materi trigonometri tersebut dianggap sulit oleh siswa, di antaranya pada pokok bahasan jumlah selisih dua sudut dan sudut ganda. Rata-rata nilai ulangan harian siswa dalam materi trigonometri pada tahun ajaran 2016/2017 adalah 30. Nilai ulangan harian siswa tersebut belum mencapai mencapai nilai Kriteria Ketuntasan Minimum (KKM) sebesar 66, sekitar 94,16\% siswa harus melakukan perbaikan. Hal tersebut juga teramati selama peneliti melakukan tugas Program Pengalaman Lapangan (PPL) di SMA Negeri 10 Singkawang. Peneliti melihat bahwa siswa mengalami kesulitan dalam menyelesaikan soal yang menuntut kemampuan berfikir matematika siswa terutama dalam hal menghubungkan antar konsep yang telah dipelajari dengan konsep baru dipelajari. Hal tersebut terungkap dari wawancara dengan guru matematika yang berkaitan bahwa sebagaian besar siswa hanya menghafal rumus trigonometri dan tidak memahami konsep rumus trigonometri tersebut sehingga siswa sering mengalami kesulitan dalam menyelesaikan soal trigonometri.

Materi yang dipilih dalam penelitian ini adalah materi trigonometri, dimana materi tersebut telah diajarkan di SMA Negeri 10 Singkawang. Sedangkan materi trigonometri yang akan dikaji dalam penelitian ini, dikhususkan pada submateri jumlah selisih dua sudut dan sudut ganda. Berdasarkan uraian di atas, rendahnya hasil belajar siswa pada materi trigonometri menjadi pertimbangan peneliti dalam memilih materi ini dikarenakan masih banyak siswa yang tidak menguasai materi trigonometri terutama pada submateri jumlah selisih dua sudut dan sudut ganda yang akan dikaji pada penelitian ini. Hal ini dikarenakan jumlah selisih dua sudut dan sudut rangkap trigonometri memiliki konsep rumus yang beragam dan ini menyulitkan siswa yang tidak menguasai konsep trigonometri sebelumnya. Sehingga siswa tidak bisa menghubungkan antarkonsep trigonometri dengan topik matematika lainnya dan dalam kehidupan sehari-hari Berdasarkan uraian di atas, peneliti tertarik untuk melakukan penelitian terhadap kemampuan koneksi matematis siswa SMA Negeri 10 Singkawang kelas XI pada materi trigonometri.

\section{METODE}

Jenis penelitian yang digunakan dalam penelitian ini adalah penelitian penelitian deskriptif atau description research dengan pendekatan kualitatif. Menurut Nawawi (2015: 38-39) metode deskriptif 
merupakan prosedur pemecahan masalah yang diselidiki dengan menggambar/melukiskan keadaan subyek/obyek penelitian. Sedangkan model yang digunakan adalah model kualitatif. Menurut Sugiyono (2012: 9) penelitian kualitatif adalah metode penelitian yang berlandaskan pada filsafat postpositive yang digunakan untuk meneliti pada kondisi obyek yang alamiah (sebagai lawannya eksperimen) dimana peneliti adalah sebagai instrumen kunci, teknik pengumpulan data dilakukan secara dokumentasi dan triangulasi (gabungan), analisis data bersifat induktif/kualitatif dan hasil penelitian kualitatif lebih menekankan makna daripada generalisasi. Tujuan dari penelitian ini adalah untuk mencari informasi serta mendeskriptifkan tingkat kemampuan koneksi matematis siswa, kesalahan siswa dalam menyelesaikan soal, dan faktor yang mempengaruhi siswa dalam menyelesaikan soal pada materi trigonometri kelas XI SMA Negeri 10 Singkawang.

Teknik pengumpulan data dalam penelitian ini adalah teknik pengukuran yaitu dengan memberikan tiga soal tes tertulis (essay) yang mencakup tiga indikator kemampuan koneksi matematis yaitu (1) mencari hubungan berbagai representasi konsep dan prosedur, (2) memahami hubungan di antara topik matematika, (3) menerapkan matematika dalam bidang studi lain. Untuk menghitung hasil tes tersebut menggunakan teknik penskoran yaitu dengan memberikan siswa skor pada setiap butir soal yang dijawab benar sesuai dengan tabel penskoran dan kunci jawaban. Teknik pengumpulan data yang kedua yaitu teknik komunikasi langsung yaitu dengan wawancara (interview) untuk mengetahui faktor yang mempengaruhi siswa melakukan kesalahan dalam menyelesaikan soal trigonometri berdasarkan indikator kemampuan koneksi matematis.

Teknik analisis data yang digunakan dalam penelitian ini adalah teknik analisis interaktif yang dikembangkan oleh Miles dan Huberman (dalam Sugiyono, 2013: 246). Teknik analisis interaktif terdiri atas tiga komponen yaitu reduksi data, penyajian data, dan penarikan kesimpulan

\section{HASIL DAN PEMBAHASAN}

\section{A. Tingkat Kemampuan Koneksi Matematis Siswa}

Tingkat kemampuan koneksi matematis siswa diperoleh berdasarkan hasil tes tertulis (essay) sebanyak 3 soal materi trigonometri. Soal tes tersebut mengandung 3 indikator yaitu mencari hubungan berbagai representasi konsep dan prosedur, memahami hubungan di antara topik matematika, dan menerapkan matematika dalam bidang studi lain. Data tersebut diperoleh melalui pemberian instrumen kepada siswa berupa tes kemampuan koneksi matematis. Setelah pemberian instrumen tes, hasil tes siswa dikumpulkan maka jawaban dari tes siswa tersebut akan dikoreksi dan ditabulasi. Selanjutnya, dari tabulasi jawaban siswa ditentukan berdasarkan kriteria tingkat kemampuan. Berdasarkan data yang diperoleh terdapat 4 siswa yang memenuhi Kriteria Ketuntasan Minimal (KKM) dan 26 siswa lainnya belum mencapai Kriteria Ketuntasan Minimal (KKM) yaitu di bawah angka 66. Selanjutnya, hasil tes kemampuan koneksi matematis siswa tersebut diurutkan dari nilai tertinggi sampai nilai yang terendah.

Kemampuan koneksi matematis siswa tersebut, akan diberi kriteria yaitu sangat baik, baik, cukup, kurang, atau sangat kurang. Kemudian dari hasil tes siswa tersebut, dapat ditabulasikan menjadi tingkat kemampuan koneksi matematis siswa per kelompok siswa dan per indikator. Tingkat kemampuan koneksi matematis siswa per kelompok dapat dilihat dengan mengelompokkan siswa menjadi 3 kelompok yaitu siswa kelompok atas, tengah, dan bawah. Sedangkan tingkat kemampuan koneksi matematis siswa per indikator, dapat dilihat dari ketiga indakator kemampuan koneksi matematis dalam peneletian ini.

Berikut ini, tabulasi perhitungan tingkat kemampuan koneksi matematis siswa secara keselurahan akan disajikan secara ringkas dalam Tabel 1 sebagai berikut. 
Tabel 1 Rekapitulasi Tingkat Kemampuan Koneksi Matematis Siswa Secara Keseluruhan

\begin{tabular}{rcccc}
\hline Rentang Skor & Kriteria & $\begin{array}{c}\text { Banyak } \\
\text { Siswa }\end{array}$ & $\begin{array}{c}\text { Rata-rata \% } \\
\text { Skor Siswa }\end{array}$ & $\begin{array}{c}\text { Rata-rata \% } \\
\text { Skor Siswa } \\
\text { Keseluruhan }\end{array}$ \\
\hline $80 \%<\mathrm{N} \leq 100 \%$ & $\begin{array}{c}\text { Sangat } \\
\text { Baik }\end{array}$ & 0 & 0 & \\
$60 \%<\mathrm{N} \leq 80 \%$ & Baik & 6 & 20,00 & \\
$40 \%<\mathrm{N} \leq 60 \%$ & Cukup & 14 & 46,67 & 46,67 \\
$20 \%<\mathrm{N} \leq 40 \%$ & Kurang & 9 & 30,00 & (Cukup) \\
$0 \%<\mathrm{N} \leq 20 \%$ & $\begin{array}{c}\text { Sangat } \\
\text { Kurang }\end{array}$ & 1 & 3,33 & \\
\cline { 2 - 3 } Jumlah & & 30 & & \\
\hline
\end{tabular}

Dari Tabel 1 di atas diketahui bahwa rata-rata skor siswa secara keseluruhan siswa SMA Negeri 10 Singkawang kelas XI IPA pada materi trigonometri tergolong cukup. Sedangkan, untuk mengetahui tingkat kemampuan koneksi matematis per kelompok, dapat dilihat pada Tabel 2 berikut.

Tabel 2 Rekapitulasi Tingkat Kemampuan Koneksi Matematis Siswa Per Kelompok

\begin{tabular}{ccc}
\hline & $\begin{array}{c}\text { Rata-rata } \% \\
\text { Skor } \\
\text { Kelompok } \\
\text { Siswa }\end{array}$ & Kriteria \\
\hline Kelompok Siswa & 66,00 & Baik \\
Kelompok Tengah & 46,00 & Cukup \\
Kelompok Bawah & 28,00 & Kurang \\
\hline
\end{tabular}

Dari Tabel 2 di atas terlihat bahwa tingkat kemampuan koneksi matematis siswa untuk kelompok atas lebih tinggi dibandingkan dengan kelompok tengah dan kelompok bawah. Untuk mengetahui presentase tingkat kemampuan koneksi matematis siswa per indikator dapat dilihat pada Tabel 3 sebagai berikut.

Tabel 3 Tingkat Kemampuan Koneksi Matematis Siswa Per Indikator

\begin{tabular}{rlcc}
\hline No Soal & $\begin{array}{l}\text { Indikator } \\
\text { Kemampuan } \\
\text { Koneksi Matematis }\end{array}$ & $\begin{array}{l}\text { Rata-rata } \\
\text { Per Indikator (\%) }\end{array}$ & Kriteria \\
\hline 1. & $\begin{array}{l}\text { Mencari hubungan } \\
\text { berbagai } \\
\text { representasi dan } \\
\text { konsep } \\
\text { prosedur }\end{array}$ & Cukup \\
2. & $\begin{array}{l}\text { Memahami } \\
\text { hubungan di antara } \\
\text { topik matematika } \\
\text { Menerapkan } \\
\text { matematika dalam } \\
\text { bidang studi lain }\end{array}$ & 47.92 & Cukup \\
& 30.00 & Kurang \\
\hline
\end{tabular}

Dari Tabel 3 di atas, diperoleh bahwa tingkat kemampuan koneksi matematis siswa pada indikator mencari hubungan berbagai representasi konsep dan prosedur dan indikator memahami hubungan di antara topik matematika tergolong cukup. Sedangkan, untuk indikator menerapkan matematika dalam bidang studi lain tergolong kurang. 
Berdasarkan uraian di atas, secara keseluruhan tingkat kemampuan koneksi matematis siswa tergolong cukup dengan skor sebesar 46,67\%. Tingkat kemampuan koneksi matematis siswa dikatakan cukup karena siswa dapat menentukan konsep rumus trigonometri yang digunakan dan cukup dalam memahami hubungan antara bangun limas dengan rumus trigonometri, akan tetapi siswa kurang dapat menjelaskan hubungan antara konsep dengan prosedur dan menerapkan matematika dalam bidang studi lain.

Hal ini sejalan dengan penelitian Ni'mah (2017) bahwa siswa yang memiliki kemampuan koneksi matematis cukup, dapat menuliskan konsep yang mendasari jawaban dengan baik dan memahami masalah kehidupan sehari-hari dalam model matematika dengan baik akan tetapi tidak dapat menuliskan hubungan antara konsep matematika dengan objek dengan baik.

Berdasarkan pemaparan di atas, dapat disimpulkan bahwa tingkat kemampuan koneksi matematis siswa masing-masing indikator diperoleh data persentase pada indikator pertama dan kedua cukup baik dibandingkan dengan indikator ketiga. Sedangkan, untuk masing-masing kelompok diperoleh data dari persentase siswa kelompok atas dan kelompok tengah dapat dikatakan cukup baik dibandingkan siswa kelompok bawah.

\section{B. Kesalahan Kemampuan Koneksi Matematis Siswa}

Kesalahan siswa dalam menyelesaikan soal trigonometri dibagi menjadi dua jenis yaitu kesalahan konseptual dan kesalahan prosedural. Berdasarkan indikator mencari hubungan berbagai representasi konsep dan prosedur terdapat kesalahan konseptual yang dilakukan siswa dalam menyelesaikan soal trigonometri yaitu 1) salah dalam menerjemahkan soal ke dalam model matematika seperti salah dalam mengubah perkalian dua sudut sinus dalam model matematika 2) salah dalam menentukan jawaban akhir seperti menjelaskan hubungan pada langkah-langkah yang digunakan. Sedangkan kesalahan prosedural yang dilakukan siswa dalam menyelesaikan soal trigonometri yaitu 1) tidak mampu memanipulasi langkah seperti tidak memperoleh nilai perkalian cosines alfa dengan cosines beta berdasarkan soal yang telah diketahui 2) salah dalam melakukan perhitungan matematika seperti salah menambahkan atau mengurangkan 3) siswa tidak melanjutkan proses penyelesaian soal trigonemetri 3) langkah penyelesian soal tidak sistematis.

Berdasarkan indikator memahami hubungan di antara topik matematika terdapat kesalahan kesalahan konseptual yang dilakukan siswa dalam menyelesaikan soal trigonometri yaitu 1) salah dalam memahami soal seperti tidak dapat membedakan tinggi limas dengan tinggi alas limas pada soal 2) salah dalam menentukan rumus yang akan digunakan seperti rumus cosinus sudut rangkap 2) salah dalam menggunakan aturan matematika dengan benar. Sedangkan, kesalahan prosedural konseptual yang dilakukan siswa dalam menyelesaikan soal trigonometri yaitu 1) Langkah penyelesaian soal tidak sitematis seperti siswa mencari penyelesaian cosinus sudut rangkap terlebih dahulu padahal seharusnya mencari luas alas limas terlebih dahulu 2) salah dalam melakukan perhitungan matematika seperti pengurangan atau penjumlahan 3) tidak melanjutkan proses penyelesaian.

Kemudian, berdasarkan indikator menerapkan matematika dalam bidang studi lain terdapat kesalahan konseptual yang dilakukan siswa dalam menyelesaikan soal trigonometri yaitu 1) salah dalam memahami makna soal seperti siswa tidak memahami bahwa soal tersebut seharusnya dapat diselesaikan menggunakan rumus cosinus penjumlahan trigonometri 2) salah dalam menggunakan rumus seperti rumus jumlah dua sudut trigonometri. Sedangkan, kesalahan prosedural yang dilakukan siswa dalam menyelesaikan soal trigonometri yaitu 1) tidak melanjutkan proses penyelesaian 2) salah dalam melakukan perhitungan matematika seperti pengurangan atau penjumlahan.

Kesalahan konseptual dan prosedural dalam penelitian ini, sejalan dengan penelitian Sari (2013) di mana kesalahan siswa dalam menyelesaikan soal meliputi kesalahan konseptual dan kesalahan prosedural. Hal tersebut dibenarkan oleh pendapat Kastolan (dalam Sulistyarini, 2014) yang 
menyebutkan bahwa jenis-jenis kesalahan yang dilakukan oleh siswa dalam menyelesaikan soal antara lain kesalahan konseptual dan kesalahan prosedural.

Berdasarkan pemaparan di atas, dapat disimpulkan bahwa kesalahan yang dilakukan siswa dalam menyelesaikan soal trigonometri meliputi kesalahan konseptual seperti salah dalam memahami soal, salah dalam menggunakan rumus, salah menerjemahkan soal ke dalam kalimat matematika, salah dalam menentukan rumus yang akan digunakan, dan salah dalam mementukan jawaban akhir dan kesalahan prosedural seperti langkah penyelesaian tidak sistematis, tidak mampu memanipulasi langkah, tidak melanjutkan proses penyelesaian, dan kesalahan dalam melakukan proses perhitungan matematika.

\section{Faktor yang Mempengaruhi Kesalahan Siswa}

Faktor yang mempengaruhi kesalahan siswa dalam menyelesaikan soal trigonometri untuk indikator mencari hubungan berbagai representasi konsep dan prosedur meliputi faktor kesalahan konseptual yaitu kurang teliti dalam menyelesaikan soal, kurangnya penguasaan bahasa terhadap permintaan soal, dan kurangnya pemahaman siswa terhadap materi trigonometri. Selain itu, terdapat faktor kesalahan prosedural yaitu kurang teliti dalam melakukan perhitungan dan kurang paham terhadap materi trigonometri.

Faktor yang mempengaruhi kesalahan siswa dalam menyelesaikan soal trigonometri untuk indikator memahami hubungan di antara topik matematika meliputi faktor kesalahan konseptual yaitu siswa kurang teliti dalam menyelesaikan soal, kurang paham terhadap soal, dan lupa dengan rumus yang akan digunakan. Selain itu, terdapat faktor kesalahan prosedural yaitu tergesa-gesa dalam menyelesaikan soal, kurang teliti dalam melakukan perhitungan, dan kurangnya pemahaman siswa terhadap materi trigonometri.

Faktor yang mempengaruhi kesalahan siswa dalam menyelesaikan soal trigonometri untuk indikator menerapkan matematika dalam bidang studi lain meliputi faktor kesalahan konseptual yaitu kurang paham terhadap materi trigonometri dan tidak memahami maksud soal yang diberikan. Selain itu, terdapat faktor kesalahan prosedural yaitu lupa rumus yang akan digunakan dan tidak memahami maksud soal.

Sejalan dengan menurut Wardoyo (2013) faktor-faktor penyebab kesalahan bila ditinjau dari kesalahan dan kemampuan belajar siswa yaitu kurangnya penguasaan bahasa sehingga menyebabkan siswa kurang paham terhadap permintaan soal, yang dimaksud kurang paham terhadap permintaan soal adalah siswa tidak tahu yang akan dia kerjakan setelah dia memperoleh informasi dari soal namun terkadang siswa juga tidak tahu apa informasi yang berguna dari soal karena terjadi salah penafsiran, kurangnya pemahaman siswa terhadap materi prasyarat (baik dari segi sifat, rumus dan prosedur pengerjaan), kebiasaan siswa dalam menyelesaikan soal masalah matematika dalam bentuk cerita misalnya siswa tidak mengembalikan jawaban model menjadi jawaban permasalahan, kurangnya minat terhadap pelajaran matematika atau ketidakseriusan siswa dalam mengikuti pelajaran, siswa tidak belajar walaupun ada tes atau ulangan, lupa rumus yang akan digunakan untuk menyelesaikan soal, salah memasukan data, tergesa-gesa dalam menyelesaikan soal, kurang teliti dalam menyelesaikan soal.

Selain itu, sejalan juga dengan pendapat Suwarsono (dalam Sari, 2015) tentang faktor penyebab kesalahan dalam belajar matematika adalah faktor kognitif yaitu faktor-faktor yang berhubungan dengan kemampuan intelektual siswa dan cara siswa merespon atau mencerna dalam pikirannya materi matematika seperti soal-soal, argumen-argumen, dan lain-lain. Berdasarkan pemaparan di atas, dapat disimpulkan bahwa faktor yang mempengaruhi kesalahan siswa dalam menyelesaikan soal meliputi faktor kesalahan konseptual (kurang teliti dalam menyelesaikan soal, kurangnya penguasaan bahasa terhadap permintaan soal, kurangnya pemahaman siswa terhadap materi trigonometri, kurang teliti dalam menyelesaikan soal dan lupa denga rumus yang akan digunakan) dan faktor kesalahan 
prosedural (kurang teliti dalam melakukan perhitungan, tergesa-gesa dalam menyelesaikan soal, kurangnya pemahaman siswa terhadap materi trigonometri, lupa rumus yang akan digunakan dan tidak memahami maksud soal).

\section{KESIMPULAN DAN SARAN}

Berdasarkan hasil analisis yang dikemukakan oleh peneliti pada bab IV sebelumnya, maka dapat disimpulkan bahwa kemampuan koneksi matematis siswa pada materi trigonometri kelas XI SMA Negeri 10 Singkawang berdasarkan rumusan masalah sebagai berikut.

Tingkat kemampuan koneksi matematis siswa kelas XI SMA Negeri 10 Singkawang secara keseluruhan sebesar 46,67\% dengan kriteria cukup. Untuk tingkat kemampuan koneksi matematis siswa pada pada indikator pertama yaitu mencari hubungan berbagai representasi konsep dan prosedur sebesar 53,75\% dengan kriteria cukup, pada indikator kedua yaitu memahami hubungan di antara topik matematika sebesar $47,92 \%$ dengan kriteria cukup, dan pada indikator ketiga yaitu menerapkan matematika dalam bidang studi lain sebesar 30\% dengan kriteria sangat kurang. Sedangkan untuk tingkat kemampuan koneksi siswa kelompok atas sebesar $66 \%$ dengan kriteria baik, siswa kelompok tengah sebesar $46 \%$ dengan kriteria cukup, dan siswa kelompok bawah sebesar $28 \%$ dengan kriteria kurang.

Kesalahan siswa dalam menyelesaikann soal kemampuan koneksi matematis siswa pada materi trigonometri kelas XI SMA Negeri 10 Singkawang meliputi kesalahan konseptual (salah dalam menggunakan rumus, salah menerjemahkan soal ke dalam kalimat matematika, salah dalam menentukan rumus yang akan digunakan, salah memahami soal, dan salah dalam mementukan jawaban akhir) dan kesalahan prosedural (langkah penyelesaian tidak sistematis, tidak melanjutkan proses penyelesaian, dan kesalahan dalam melakukan proses perhitungan).

Faktor yang mempengaruhi kesalahan siswa dalam menyelesaikan soal kemampuan koneksi matematis siswa pada materi trigonometri kelas XI SMA Negeri 10 Singkawang meliputi faktor kesalahan konseptual (kurang teliti dalam menyelesaikan soal, kurangnya penguasaan bahasa terhadap permintaan soal, kurangnya pemahaman siswa terhadap materi trigonometri, kurang teliti dalam menyelesaikan soal dan lupa denga rumus yang akan digunakan) dan faktor kesalahan prosedural (kurang teliti dalam melakukan perhitungan, tergesa-gesa dalam menyelesaikan soal, kurangnya pemahaman siswa terhadap materi trigonometri, lupa rumus yang akan digunakan dan tidak memahami maksud soal).

\section{DAFTAR PUSTAKA}

Aqiilah, 2012, "Analisis kesalahan Peserta Didik dalam Menyelesaikan Soal Pembuktian Identitas Trigonometri Kelas X.1 SMA Islam Sultan Agung 1 Semarang Tahun Pelajaran 2011/2012". Skripsi. Institut Agama Islam Negeri Walisongo Semarang. Dipublikasikan.

BSNP. 2006. Standar Isi untuk Satuan Pendidikan Dasar dan Menengah. Jakarta: Badan Standar Nasional.

Buyung, B., \& Nirawati, R. (2018). Pengaruh Karakter Kerja Keras Terhadap Kemampuan Literasi Matematis Siswa Melalui Model Discovery Learning. JPMI (Jurnal Pendidikan Matematika Indonesia), 3(1), 21-25.

Citra, dkk. 2016, "Implementation Of Brain-Based Learning Model To Increase Students' Mathematical Connection Ability On Trigonometry At Senior High Schoo". Jurnal Proceedings of the $20182^{\text {nd }}$ International conference on Education and E-learning. STKIP Singkawang.

Lestari, Kurnia Eka dan Yudhanegara, Mokhammad Ridwan. 2015. Penelitian Pendidikan Matematika. Bandung: PT Refika Aditama. 
Musriliani, dkk. 2015, "Pengaruh Pembelajaran Contextual Teaching Learning (CTL) terhadap Kemampuan Koneksi Matematis Siswa SMP Ditinjau dari Gender". Jurnal Didaktik Matematika. Universitas Syiah Kuala Banda Aceh. Vol. 2, No 2, September 2015.

Nawawi, Hadar. 2015. Metode Penelitian di Bidang Sosial. Yogyakarta: Gadjah Mada University Press.

Ni'mah, A. F. 2017, “Analisis Kemampuan Koneksi Matematis Siswa Kelas IX A MTs Negeri 1 Jember Subpokok Bahasan Kubus dan Balok". Jurnal Edukasi. Universitas Jember

Romli, Muhammad. 2016, "Profil Koneksi Matematis Siswa Perempuan SMA dengan Kemampuan Matematika Tinggi dalam Menyelesaikan Masalah Matematika". Jurnal of Mathematics Education, Science and Technology. Universitas Negeri Surabaya. Vol. 1, No. 2, Desember 2016.

Sari, Elizabeth Kurnia. 2016, "Analisis kesalahan siswa Dalam Menyelesaikan Sola Matematika Pada Pokok bahasan Lingkaran Kelas VIII B SMP Kanisius Kalasan Yogyakarta". Skripsi. Universitas Sanata Dharma Yogyakarta. Dipublikasikan.

Sari, Kartika Dewi. 2015, "Analisis Kesalahan Siswa Kelas VIII SMP BOPKRI 2 Yogyakarta Dalam Mengerjakan Soal-soal Operasi Bentuk Aljabar Tahun Ajaran 2014/2015". Skripsi. Universitas Sanata Dharma Yogyakarta. Dipublikasikan.

Sugiyono. 2012. Metode Penelitian Pendidikan Pendekatan Kuantitatif, Kualitatif, dan R\&D. Bandung: Penerbit Alfabeta.

Sugiyono. 2013. Metode Penelitian Pendidikan Pendekatan Kuantitatif, Kualitatif, dan R\&D. Bandung: Penerbit Alfabeta.

Sulistyarini, Dyah Ayu. 2016, "Analisis Kesulitan Siswa SMK Citra Medika Sukoharjo Dalam Menyelesaikan Soal Bentuk Akar dan Alternatif Pemecahannya". Prosiding, Universitas Sebelas Maret.

Wardoyo, 2013. "Analisis Kesalahan Kelas X-1 SMA Negeri 1 Curup Tengah Dalam Menyelesaikan Masalah Divergen Tentang Sistem Persamaan Linear Dua Peubah". Tesis. Universitas Bengkulu. Dipublikasikan.

Warih, dkk. 2016, “Analisis Kesalahan Koneksi Matematis Siswa Pada Materi Sistem Persamaan Linear Dua Variabel”. Jurnal Prosiding. ISSN: 2502-6526. Universitas Muhammadiyah Surakarta, 12 Maret 2016. 